\title{
Synthesis of a fluorogenic substrate for $\alpha$-L-iduronidase
}

\author{
Fu-Chieh Lu, ${ }^{a}$ Larry S. Lico, ${ }^{a}$ and Shang-Cheng Hung* ${ }^{\text {a,b }}$ \\ ${ }^{a}$ Genomics Research Center, Academia Sinica, No. 128, Section 2, Academia Road, Taipei 115, \\ Taiwan \\ ${ }^{b}$ Department of Applied Chemistry, National Chiao-Tung University, No. 1001, Ta-Hsueh Road, \\ Hsinchu 300, Taiwan \\ E-mail: schung@gate.sinica.edu.tw
}

\section{Dedicated to Professor Richard R. Schmidt on the occasion of his 78th birthday}

\begin{abstract}
An alternative reaction pathway towards the preparation of an L-idopyranose derivative and its application to the synthesis of the $\alpha$-L-iduronidase fluorogenic substrate 4-methylcoumarin-7-yl$\alpha$-L-iduronic acid as well as its 3-undecyl derivative are described. The L-ido sugar was prepared by converting the commercially available diacetone- $\alpha$-D-glucose to methyl $1,2,3,4$-tetra- $O$ acetyl-L-idopyranuronate via oxidation, esterification, and regioselective acetylation of the key intermediate 1,2:3,5-di- $O$-isopropylidene- $\beta$-L-idofuranose. Mitsunobu-type glycosylation was employed in the coupling of the L-ido donor with the 4-methylcoumarin acceptors. This newly developed route reduced the difficulties previously encountered in the synthesis of the $\alpha-\mathrm{L}-$ iduronidase fluorogenic substrate.
\end{abstract}

Keywords: L-Iduronic acid, Mitsunobu-type glycosylation, mucopolysaccharidosis, fluorogenic substrate, $\alpha$-L-iduronidase

\section{Introduction}

Mucopolysaccharidosis I (MPS I) is a genetic disorder caused by the body's inability to make an enzyme called $\alpha$-L-iduronidase (IDUA), ${ }^{1}$ one of the enzymes involved in the degradation of glycosaminoglycans. Failure of IDUA to hydrolyze dermatan sulfate and heparan sulfate can lead to the accumulation of partially degraded products in lysosomes, which can result to cell, tissue, and organ dysfunction. Generally, the disease can manifest as milder condition but there are severe cases that can lead to death during the first decade of life. ${ }^{2}$ Currently, both hematopoietic stem cell transplantation and enzyme replacement therapy are available for the 
treatment of MPS I, ${ }^{3}$ but early detection is essential to avoid the severe progression of the disease. $^{4}$

One well-known technique used for the diagnosis of all clinical types of MPS I is the measurement of IDUA activity, ${ }^{5}$ wherein 4-methylcoumarin-7-yl- $\alpha$-L-iduronic acid (4) is used as fluorogenic substrate. ${ }^{6}$ However, this particular substrate is very expensive (>US\$100 per mg) primarily because of the relative unavailability and difficult synthesis of the L-idose moiety. In addition, the 4-methylcoumarin group has poor water solubility, and IDUA activity assays require a wide range of substrate concentration. ${ }^{7}$ Although several synthetic approaches have been reported on the synthesis of L-ido sugars and their coumarin derivatives, the strategy still involves tedious steps and remains low yielding at the glycosylation stage. ${ }^{6,8}$ Thus, we explored and developed alternative methods of preparing L-ido sugars, ${ }^{8 c, d, 9}$ such as compound $\mathbf{3}$, from different D-glucose derivatives and used these materials as key intermediates for the synthesis of the fluorogenic substrate 4 .



Scheme 1. Previous synthetic pathways for the synthesis of the L-ido sugar 3 and compound 4.

Scheme 1 outlines the synthetic pathways we established for the preparation of compounds 3 and 4 from either 3,5-O-benzylidene-1,2- $O$-isopropylidene- $\alpha$-D-glucopyranose ${ }^{8 c}(\mathbf{1})$ or diacetone$\alpha$-D-glucose ${ }^{8 \mathrm{~d}}(\mathbf{2})$. Although the overall yields were relatively good, most reactions are difficult to perform and each step requires tedious purification. Furthermore, the glucopyranose derivative 1 is more expensive than other D-glucose derivatives. This led us to explore other reaction pathways that would provide the best synthetic route for the synthesis of L-ido derivatives and the fluorogenic substrate $\mathbf{4}$ from the commercially available and cheap compound 2. We report herein the progress of our work.

\section{Results and Discussion}

Our vision for the preparation of the L-ido sugars is based on the double ketal fixation of the 1,2 and 3,5-hydroxy groups of D-glucose to form a cis-anti-cis-fused tricyclic D-glucofuranosyl derivative, which could undergo elimination to form a 5-exo-double bond followed by 
electrophilic addition to give the desired products. ${ }^{8 d, 9 a}$ Accordingly, further studies were carried out to determine an alternative and efficient synthetic route for the L-ido synthesis using the cheaper compound $\mathbf{2}$ as the starting material (Scheme 2).

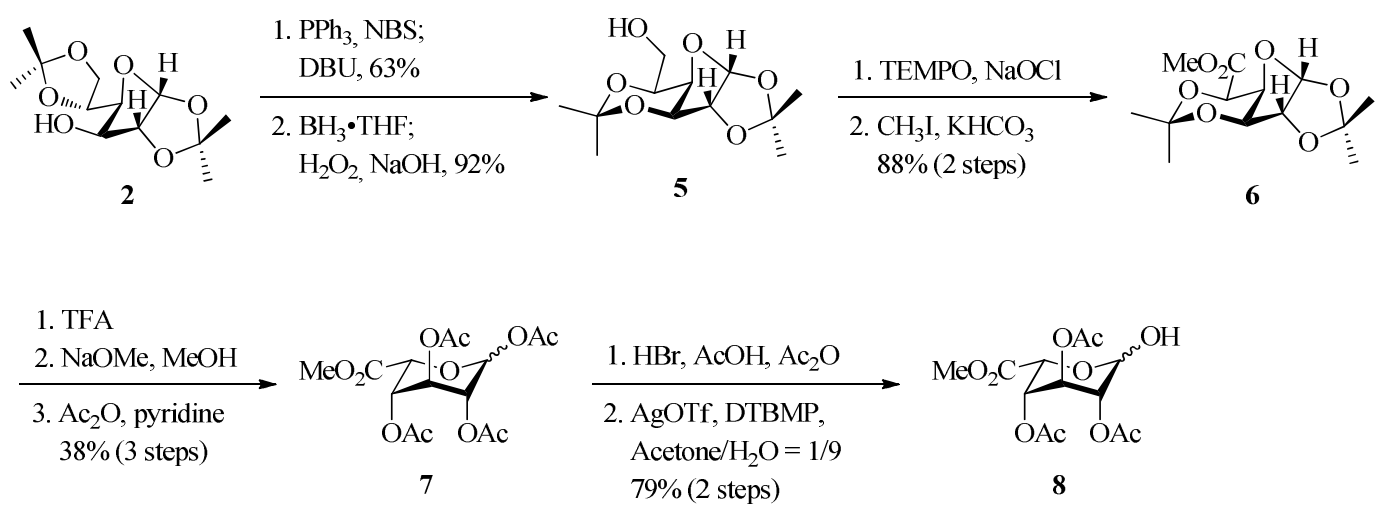

Scheme 2. Preparation of 2,3,4-tri- $O$-acetyl-L-idopyranuronate methyl ester (8).

The L-idofuranose derivative $\mathbf{5}$ was readily acquired from the highly selective hydroboration of the enol ether generated after treatment of the 3-alcohol 2 with triphenylphosphine, $\mathrm{N}$ bromosuccinimide (NBS), and freshly distilled 1,8-diaza-bicyclo[5.4.0]undec-7-ene (DBU). ${ }^{8 \mathrm{~d}}$ In our previous reports, exposure of this L-ido derivative with ethanolic- $\mathrm{HCl}$ solution furnished compound 3. ${ }^{8 \mathrm{~d}, 9}$ We opted not to follow this synthetic route to avoid the more complicated steps upon coupling of the sugar with the coumarin moiety ${ }^{8 \mathrm{~d}}$ and pursued an alternative approach in preparing the L-ido sugar donor. Oxidation of compound 5 was performed using 2,2,6,6tetramethyl-1-piperidinyloxy free radical (TEMPO) to produce the corresponding carboxylic acid which underwent methylation $\left(\mathrm{CH}_{3} \mathrm{I}, \mathrm{KHCO}_{3}\right)$ to form the ester $\mathbf{6}$ in a two-step yield of $88 \%$. Hydrolysis of the isopropylidene protecting groups in $\mathbf{6}$ using trifluoroacetic acid (TFA) immediately followed, without further purification, by peracetylation $\left(\mathrm{Ac}_{2} \mathrm{O}\right.$, pyridine) unfortunately delivered the tetraacetate 7 in only $17 \%$ yield. We found that lactone formation occurred as a major side-reaction upon treatment of $\mathbf{6}$ with TFA. The yield was improved to $38 \%$ when the products after acid hydrolysis were subjected to $\mathrm{NaOMe}$ prior to peracetylation. Bromination of the anomeric carbon using $\mathrm{HBr}$ in acetic acid followed by AgOTf-promoted hydration successfully converted 7 into the desired L-ido hemiacetal 8 (79\% in two steps).

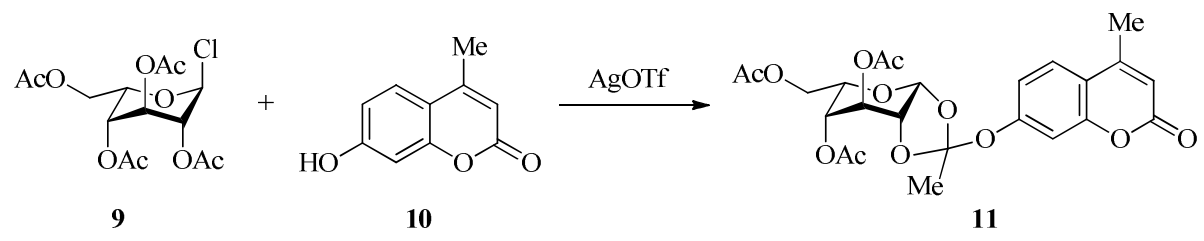

Scheme 3. Formation of an orthodiester with AgOTf as coupling agent. 
We have already tried to synthesize the target molecule 4 through the coupling of the donor 9 with 7-hydroxy-4-methylcoumarin (10) in the presence AgOTf as promoter (Scheme 3). ${ }^{8 \mathrm{~d}}$ However, the orthoester $\mathbf{1 1}$ was the major product isolated instead of the desired $\alpha$-adduct. Using this knowledge, we decided to explore a Mitsunobu-type glycosylation reaction for the coupling of the hemiacetal $\mathbf{8}$ with the acceptor $\mathbf{1 0 .}$
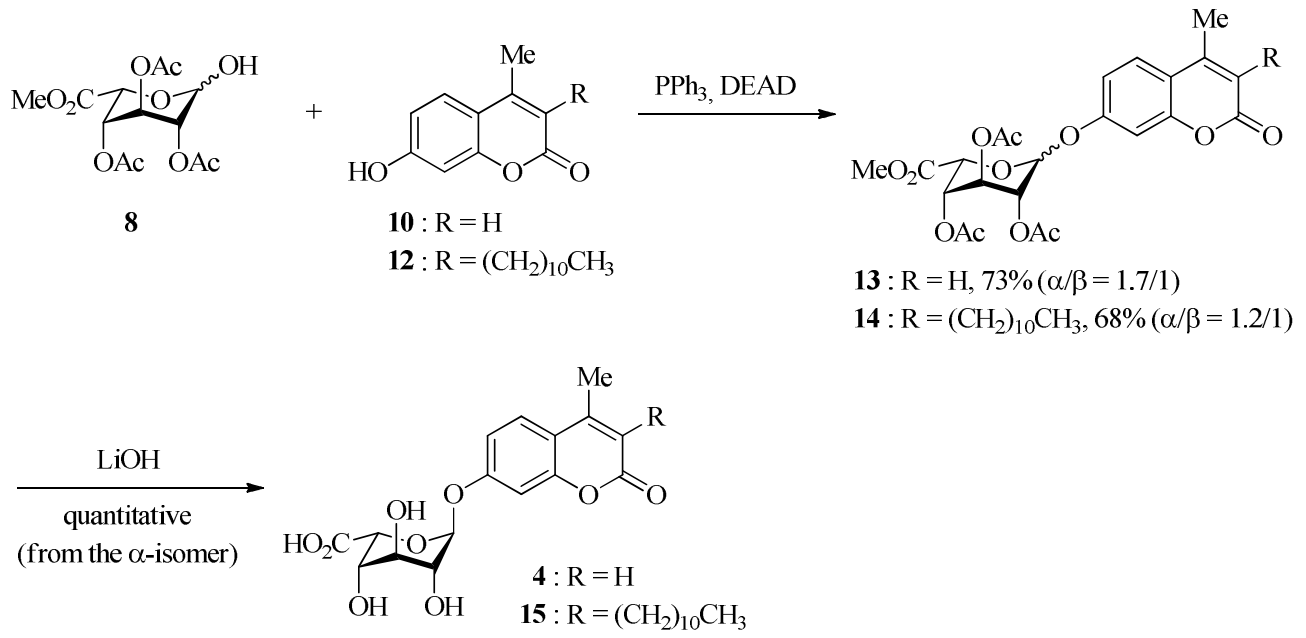

Scheme 4. Preparation of compound 4 and its 3-undecyl derivative 15.

The coumarin 10 was first prepared via Pechmann condensation of resorcinol and ethyl acetoacetate. $^{10}$ With the donor and acceptor blocks in hand, the glycosylation was performed using $\mathrm{PPh}_{3}$ and diethyl azodicarboxylate (DEAD). This reaction produced compound $\mathbf{1 3}$ in $\mathbf{7 3 \%}$ yield $(\alpha / \beta$ 1.7/1). Saponification of the $\alpha$-anomer with $\mathrm{LiOH}$ supplied the target material 4 in excellent yield. To enable surface attachment of the fluorogenic substrate, we also synthesized the alkyl-substituted coumarin $\mathbf{1 2}$ using the same procedure utilized for the preparation of $\mathbf{1 0 .}$ The Mitsunobu-type glycosylation of $\mathbf{1 2}$ with the hemiacetal 8 afforded compound $\mathbf{1 4}$ in $68 \%$ yield $(\alpha / \beta 1.2 / 1)$. Subsequent alkaline hydrolysis of the $\alpha$-adduct generated the desired product 15.

\section{Conclusions}

We have successfully developed an alternative method for the synthesis of an L-idofuranose derivative from the cheaper and more common diacetone- $\alpha$-D-glucose. Although the yield was lower compared to the previous methods we reported, this newly established method involved reaction steps that were less tedious and more convenient to perform. Further, employing the Lido sugar synthesized from this new method for the synthesis of 4-methylcoumarin-7-yl- $\alpha$-Diduronic acid and its 3-undecyl derivative via Mitsunobu-type glycosylation avoided problems 
and difficulties previously encountered. Thus, this synthetic route is a promising development in the search for a highly efficient synthesis of the fluorogenic substrate for IDUA.

\section{Experimental Section}

General. The reaction organic solvents were purified and dried from a safe purification system. Flash column chromatography was carried out as recommended with Silica Gel 60 (230-400 mesh, E. Merck). TLC was performed on pre-coated glass plates of Silica Gel 60 F254 (0.25 $\mathrm{mm}$, E. Merck); detection was executed by spraying with a solution of $\mathrm{Ce}\left(\mathrm{NH}_{4}\right)_{2}\left(\mathrm{NO}_{3}\right)_{6}$, $\left(\mathrm{NH}_{4}\right)_{6} \mathrm{Mo}_{7} \mathrm{O}_{24}$, and $\mathrm{H}_{2} \mathrm{SO}_{4}$ in water and subsequent heating on a hot plate. ${ }^{1} \mathrm{H}$ and ${ }^{13} \mathrm{C} \mathrm{NMR}$ spectra were recorded with Bruker AMX400, AV400 and AV500 MHz instruments. Chemical shifts are measured in ppm and calibrated using the solvent peaks as reference. Mass spectra were obtained with a VG 70-250S mass spectrometer in the FAB mode. Elemental analyses were measured with a Perkin-Elmer $2400 \mathrm{CHN}$ instrument.

Methyl 1,2:3,5-di- $\boldsymbol{O}$-isopropylidene- $\boldsymbol{\beta}$-L-idofuranuronate (6). The alcohol 5 (549 $\mathrm{mg}, 2.11$ mmol) was dissolved in $\mathrm{CH}_{2} \mathrm{Cl}_{2}(25 \mathrm{~mL})$ and water $(50 \mathrm{~mL})$ with added tetra- $n$-butylammonium chloride (2.9 g, $10.4 \mathrm{mmol})$. $\mathrm{KBr}(1 \mathrm{M}$ aqueous solution, $2.2 \mathrm{~mL}, 2.2 \mathrm{mmol})$, TEMPO (330 mg, $2.11 \mathrm{mmol})$, and $\mathrm{NaHCO}_{3}(0.5 \mathrm{M}$ aqueous solution, $50 \mathrm{~mL})$ were added successively to the solution. $\mathrm{NaOCl}(13.9 \mathrm{~mL}, 8.4 \mathrm{mmol})$, pre-cooled to $0{ }^{\circ} \mathrm{C}$, was slowly added to the stirring mixture. The $\mathrm{pH}$ value of the solution at room temperature was adjusted to $\sim 10.0$ by addition of $0.5 \mathrm{M} \mathrm{NaOH}_{(\mathrm{aq})}$. The mixture was then acidified with $1.0 \mathrm{~N} \mathrm{HCl}$. The organic layer was washed with water, dried over $\mathrm{MgSO}_{4}$, filtered, and concentrated under reduced pressure. The crude residue, together with $\mathrm{KHCO}_{3}(578 \mathrm{mg}, 2.11 \mathrm{mmol})$, was dissolved in anhydrous DMF (6 mL). $\mathrm{CH}_{3} \mathrm{I}(600 \mu \mathrm{L}, 9.51 \mathrm{mmol})$ was added to the solution at $0{ }^{\circ} \mathrm{C}$ under nitrogen atmosphere. The cooling bath was removed, and the mixture was stirred at room temperature overnight. The reaction was quenched with $\mathrm{H}_{2} \mathrm{O}(5 \mathrm{~mL})$, and the product was extracted using $\mathrm{CH}_{2} \mathrm{Cl}_{2}(3 \times 5$ $\mathrm{mL}$ ). The combined organic layer was dried over $\mathrm{MgSO}_{4}$, filtered, and concentrated under reduced pressure. The residue was purified by column chromatography (EtOAc/hexanes 2/3 to 1/1) to afford the ester $6(534 \mathrm{mg}, 88 \%)$. ${ }^{1} \mathrm{H}$ NMR (500 MHz, $\left.\mathrm{CDCl}_{3}\right): \delta 5.93(1 \mathrm{H}, \mathrm{d}, J 3.6 \mathrm{~Hz}$, H-1), 4.64 (1H, d, J 2.2 Hz, H-3), 4.47 (1H, d, J 3.6 Hz, H-2), 4.34 (1H, d, J 2.2 Hz, H-5), 4.29 $(1 \mathrm{H}, \mathrm{t}, J 2.2 \mathrm{~Hz}, \mathrm{H}-4), 3.79\left(3 \mathrm{H}, \mathrm{s}, \mathrm{CO}_{2} \mathrm{CH}_{3}\right), 1.47\left(6 \mathrm{H}, \mathrm{s}, \mathrm{C}\left(\mathrm{CH}_{3}\right)_{2}, 1.43\left(3 \mathrm{H}, \mathrm{s}, \mathrm{CH}_{3} \mathrm{CCH}_{3}\right), 1.28\right.$ $\left(3 \mathrm{H}, \mathrm{s}, \mathrm{CH}_{3} \mathrm{CCH}_{3}\right) .{ }^{13} \mathrm{C} \mathrm{NMR}\left(125 \mathrm{MHz}, \mathrm{CDCl}_{3}\right): \delta 168.4(\mathrm{C}), 112.0(\mathrm{C}), 105.3(\mathrm{CH}), 98.6(\mathrm{C})$, $84.1(\mathrm{CH}), 73.7(\mathrm{CH}), 71.5(\mathrm{CH}), 68.8(\mathrm{CH}), 52.7\left(\mathrm{CH}_{3}\right), 28.9\left(\mathrm{CH}_{3}\right), 26.8\left(\mathrm{CH}_{3}\right), 26.2\left(\mathrm{CH}_{3}\right)$, $18.8\left(\mathrm{CH}_{3}\right)$; HRMS (FAB, $\left.\mathrm{MH}^{+}\right): \mathrm{m} / z$ Calcd for $\mathrm{C}_{13} \mathrm{H}_{21} \mathrm{O}_{7}$ : 289.1287, Found: 289.1295. Anal. Calcd for $\mathrm{C}_{13} \mathrm{H}_{20} \mathrm{O}_{7}$ : C, 54.16; H, 6.99. Found: C, 53.92; H, 7.02.

Methyl 1,2,3,4-tetra-O-acetyl-L-idopyranuronate (7). A solution of 6 (30 mg, $0.10 \mathrm{mmol}$ ) in 90\% aqueous TFA was kept at room temperature for $15 \mathrm{~min}$, evaporated to dryness, and 
evaporated twice with water and toluene to give a solid residue. Methanol (1 mL) containing $\mathrm{NaOMe}(2 \mathrm{mg}, 0.04 \mathrm{mmol})$ was added to the crude residue. The mixture was stirred at room temperature for $1 \mathrm{~h}$. After removing the $\mathrm{MeOH}$ under reduced pressure, the collected syrup was dissolved in a mixture of $\mathrm{Ac}_{2} \mathrm{O}(106 \mathrm{mg}, 1.04 \mathrm{mmol})$ and pyridine $(400 \mu \mathrm{L})$ at $0{ }^{\circ} \mathrm{C}$. The reaction mixture was stirred at room temperature overnight. Then, the reaction was quenched with water $(2 \mathrm{~mL})$ and $\mathrm{NaHCO}_{3(\mathrm{aq})}(2 \mathrm{~mL})$, and the crude target material was extracted with $\mathrm{CH}_{2} \mathrm{Cl}_{2}(3 \times 5 \mathrm{~mL})$. The combined organic layer was dried over $\mathrm{MgSO}_{4}$, filtered, and concentrated under reduced pressure. The residue was purified by flash column chromatography (EtOAc/hexanes 2/3), which gave compound 7 (14.7 mg, 38\%, $\alpha / \beta$ 1/3.7). The ${ }^{1} \mathrm{H}$ NMR of this compound conforms to previous report. ${ }^{11}$ For the $\alpha$-isomer: $1 \mathrm{H} \mathrm{NMR}\left(500 \mathrm{MHz}, \mathrm{CDCl}_{3}\right): \delta$ 6.29-6.24 (1H, m, H-1), 5.20-5.10 (2H, m, H-3, H-4), 4.88-4.80 (2H, m, H-2, H-5), 3.77 (3H, s, $\left.\mathrm{COOCH}_{3}\right), 2.11\left(3 \mathrm{H}, \mathrm{s}, \mathrm{OCOCH}_{3}\right), 2.09\left(3 \mathrm{H}, \mathrm{s}, \mathrm{OCOCH}_{3}\right), 2.08\left(3 \mathrm{H}, \mathrm{s}, \mathrm{OCOCH}_{3}\right), 2.06(3 \mathrm{H}, \mathrm{s}$, $\left.\mathrm{OCOCH}_{3}\right)$. For the $\beta$-isomer: $1 \mathrm{H} \mathrm{NMR}\left(400 \mathrm{MHz}, \mathrm{CDCl}_{3}\right): \delta 6.03(1 \mathrm{H}, \mathrm{d}, J 2.0 \mathrm{~Hz}, \mathrm{H}-1), 5.25$ $(1 \mathrm{H}, \mathrm{t}, J 3.48 \mathrm{~Hz}, \mathrm{H}-3), 5.08$ (1H, ddd, J 3.3, 2.4, $0.9 \mathrm{~Hz}, \mathrm{H}-4), 4.99$ (1H, ddd, J 3.6, 2.0, $0.8 \mathrm{~Hz}$, $\mathrm{H}-2), 4.69(1 \mathrm{H}, \mathrm{d}, \mathrm{J} 2.4 \mathrm{~Hz}, \mathrm{H}-5), 3.76\left(3 \mathrm{H}, \mathrm{s}, \mathrm{COOCH}_{3}\right), 2.14\left(3 \mathrm{H}, \mathrm{s}, \mathrm{OCOCH}_{3}\right), 2.12(3 \mathrm{H}, \mathrm{s}$, $\left.\mathrm{OCOCH}_{3}\right), 2.09\left(3 \mathrm{H}, \mathrm{s}, \mathrm{OCOCH}_{3}\right), 2.06\left(3 \mathrm{H}, \mathrm{s}, \mathrm{OCOCH}_{3}\right)$.

Methyl 2,3,4-tri- $\boldsymbol{O}$-acetyl-L-idopyranuronate (8). $\mathrm{Ac}_{2} \mathrm{O}(205 \mu \mathrm{L})$ was added to a solution of the tetraacetate $7(400 \mathrm{mg}, 1.06 \mathrm{mmol})$ in anhydrous $\mathrm{CH}_{2} \mathrm{Cl}_{2}(4 \mathrm{~mL})$ at room temperature under nitrogen atmosphere. The reaction flask was immersed in an ice-bath, and a $30 \%$ solution of $\mathrm{HBr}$ in acetic acid $(1.2 \mathrm{~mL}, 4.25 \mathrm{mmol})$ was added. The mixture was gradually warmed up to room temperature and stirred overnight. The whole solution was poured into an ice- $\mathrm{NaHCO}_{3(\mathrm{aq})}$ mixture $(100 \mathrm{~mL})$, and the crude target material was extracted with $\mathrm{CH}_{2} \mathrm{Cl}_{2}(3 \times 20 \mathrm{~mL})$. The organic layers were collected, combined, dried over $\mathrm{MgSO}_{4}$, filtered, and concentrated under reduced pressure. The crude residue was dissolved in $90 \%$ wet acetone $(5 \mathrm{~mL})$ at room temperature. AgOTf (310 mg, $1.17 \mathrm{mmol}$ ) and 2,6-di-tert-butyl-4-methylpyridine (DTBMP, 131 $\mathrm{mg}, 0.64 \mathrm{mmol}$ ) were consecutively added to the solution. The mixture was stirred for $2 \mathrm{~h}$, and then same amount of DTBMP (131 $\mathrm{mg}, 0.64 \mathrm{mmol})$ was added. The resulting reaction mixture was filtered through Celite, and the filtrate was concentrated under reduced pressure to give a residue, which was purified by flash column chromatography (EtOAc/hexanes 3/1) to furnish the hemiacetal 8 (281 mg, 79\%). 1H NMR (400 MHz, $\left.\mathrm{CDCl}_{3}\right): \delta 5.41-5.35(1.0 \mathrm{H}, \mathrm{m}), 5.23(0.4 \mathrm{H}$, t, $J 3.5 \mathrm{~Hz}), 5.14-5.06(2.3 \mathrm{H}, \mathrm{m}), 5.03(0.4 \mathrm{H}, \mathrm{t}, J 2.9 \mathrm{~Hz}), 4.99(1.0 \mathrm{H}, \mathrm{d}, J 2.8 \mathrm{~Hz}), 4.85-4.81$ $(0.4 \mathrm{H}, \mathrm{m}), 4.79(1.0 \mathrm{H}, \mathrm{t}, J 3.3 \mathrm{~Hz}), 4.58(0.3 \mathrm{H}, \mathrm{d}, J 2.3 \mathrm{~Hz}), 4.36(0.3 \mathrm{H}, \mathrm{d}, J 9.1 \mathrm{~Hz}), 4.20(1.0 \mathrm{H}$, d, J 5.5 Hz), 3.77-3.71 (4.1H, s × 2), 2.14-2.09 (2.3H, s × 2), $2.08(3.1 \mathrm{H}, \mathrm{s}), 2.05(3.0 \mathrm{H}, \mathrm{s})$, $2.04-2.00(4.0 \mathrm{H}, \mathrm{s} \times 2)$.

7-Hydroxy-4-methyl-3-undecyl-coumarin (12). Ethyl acetoacetate (500 mg, $3.84 \mathrm{mmol}$ ) was added to a solution of sodium ethoxide prepared from sodium metal $(88 \mathrm{mg}, 3.82 \mathrm{mmol})$ and ethanol $(10 \mathrm{~mL})$. The solution was heated to reflux. 1-Bromoundecane (994 $\mathrm{mg}, 4.23 \mathrm{mmol}$ ) was slowly added together with sodium iodide $(633 \mathrm{mg}, 4.23 \mathrm{mmol})$, and the mixture was 
refluxed for $19 \mathrm{~h}$. The mixture was cooled, and saturated $\mathrm{NH}_{4} \mathrm{Cl}_{(\mathrm{aq})}$ was added. The excess ethanol was then removed under reduced pressure. Subsequently, the product was extracted with EtOAc and the combined organic layer was washed with brine, dried over $\mathrm{MgSO}_{4}$, filtered, and concentrated under reduced pressure. The residue was purified by column chromatography to produce ethyl 2-undecyl-acetoacetate $(664 \mathrm{mg}, 61 \%) .{ }^{1} \mathrm{H} \mathrm{NMR}\left(400 \mathrm{MHz}, \mathrm{CDCl}_{3}\right): \delta 4.16(2 \mathrm{H}$, $\left.\mathrm{m}, \mathrm{CH}_{2}\right), 3.36(1 \mathrm{H}, \mathrm{t}, J 7.3 \mathrm{~Hz}, \mathrm{CH}), 2.19\left(\mathrm{~s}, 3 \mathrm{H}, \mathrm{CH}_{3}\right), 1.80\left(\mathrm{~m}, 2 \mathrm{H}, \mathrm{CH}_{2}\right), 1.24\left(\mathrm{~m}, 21 \mathrm{H}, \mathrm{CH}_{2}\right)$, $0.85\left(\mathrm{~m}, 3 \mathrm{H}, \mathrm{CH}_{2}\right)$.

To an equivalent mixture of resorcinol $(150 \mathrm{mg}, 1.36 \mathrm{mmol})$ and ethyl 2-undecyl-acetoacetate (388 mg, $1.36 \mathrm{mmol}), p$-TsOH $(52.0 \mathrm{mg}, 0.27 \mathrm{mmol}$ ) was added at room temperature. The mixture was heated at $20{ }^{\circ} \mathrm{C}$ for $20 \mathrm{~h}$. The reaction was quenched with $\mathrm{H}_{2} \mathrm{O}(5 \mathrm{~mL})$, and the desired material was extracted with $\mathrm{CHCl}_{3}(3 \times 5 \mathrm{~mL})$. The combined organic layer was dried over $\mathrm{MgSO}_{4}$, filtered, and concentrated under reduced pressure. The residue was purified by flash column chromatography (EtOAc/hexanes 1/3) to give the coumarin derivative $\mathbf{1 2}$ (350 mg, 78\%). ${ }^{1} \mathrm{H}$ NMR (500 MHz, $\left.\mathrm{CDCl}_{3}\right): \delta 8.14(1 \mathrm{H}$, br s, OH), $7.46(1 \mathrm{H}, \mathrm{d}, J 8.8 \mathrm{~Hz}, \mathrm{Ar}-\mathrm{H}), 7.06$ $(1 \mathrm{H}, \mathrm{d}, J 2.4 \mathrm{~Hz}, \mathrm{Ar}-\mathrm{H}), 6.86(1 \mathrm{H}, \mathrm{dd}, J 8.8,2.4 \mathrm{~Hz}, \mathrm{Ar}-\mathrm{H}), 2.60\left(2 \mathrm{H}, \mathrm{t}, J 7.9 \mathrm{~Hz}, \mathrm{CH}_{2}\right), 2.37$ $\left(3 \mathrm{H}, \mathrm{s}, \mathrm{CH}_{3}\right), 1.54-1.44\left(2 \mathrm{H}, \mathrm{m}, \mathrm{CH}_{2}\right), 1.40-1.32\left(2 \mathrm{H}, \mathrm{m}, \mathrm{CH}_{2}\right), 1.32-1.16\left(\mathrm{~m}, 14 \mathrm{H},\left(\mathrm{CH}_{2}\right)_{7}\right)$, $0.85\left(3 \mathrm{H}, \mathrm{t}, J 7.0 \mathrm{~Hz}, \mathrm{CH}_{3}\right) .{ }^{13} \mathrm{C} \mathrm{NMR}\left(125 \mathrm{MHz} \mathrm{CDCl}_{3}\right): \delta 163.4(\mathrm{C}), 159.2(\mathrm{C}), 153.3(\mathrm{C})$, $147.5(\mathrm{C}), 125.7(\mathrm{CH}), 123.0(\mathrm{C}), 114.0(\mathrm{C}), 113.4(\mathrm{CH}), 103.0(\mathrm{CH}), 31.9\left(\mathrm{CH}_{2}\right), 29.7\left(\mathrm{CH}_{2}\right)$, $29.64\left(\mathrm{CH}_{2}\right), 29.61\left(\mathrm{CH}_{2} \times 2\right), 29.5\left(\mathrm{CH}_{2}\right), 29.3\left(\mathrm{CH}_{2}\right), 28.9\left(\mathrm{CH}_{2}\right), 27.4\left(\mathrm{CH}_{2}\right), 22.7\left(\mathrm{CH}_{2}\right), 14.9$ $\left(\mathrm{CH}_{3}\right)$, $14.1\left(\mathrm{CH}_{3}\right)$. HRMS (FAB, $\left.\mathrm{MH}^{+}\right): \mathrm{m} / z$ Calcd for $\mathrm{C}_{21} \mathrm{H}_{31} \mathrm{O}_{3}: 331.2273$, Found: 331.2285 . Anal. Calcd for $\mathrm{C}_{21} \mathrm{H}_{30} \mathrm{O}_{3}$ : C, 76.33; H, 9.15. Found: C, 76.53; H, 8.91.

General procedure for Mitsunobu-type glycosylation. The hemiacetal 8 (102 $\mathrm{mg}, 0.31 \mathrm{mmol}$ ), $\mathrm{PPh}_{3}(120 \mathrm{mg}, 0.46 \mathrm{mmol})$, and the coumarin acceptor $(0.46 \mathrm{mmol})$ were dissolved in THF (2 $\mathrm{mL}$ ) with suspended $4 \AA$ molecular sieves at room temperature. After $1 \mathrm{~h}$, the reaction flask was immersed in an ice-bath, and DEAD $(91 \mu \mathrm{L}, 0.46 \mathrm{mmol})$ was added to the solution. The mixture was gradually warmed up to room temperature and stirred overnight. The reaction mixture was filtered through Celite, the filtrate was concentrated under reduced pressure, and the residue was collected for purification.

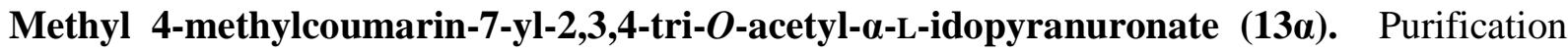
of the crude residue was performed by flash column chromatography (EtOAc/hexanes 1/1) to get compound 13a (69 mg, 46\%) and its $\beta$-isomer (41 mg, 27\%). ${ }^{1} \mathrm{H}$ NMR (500 $\left.\mathrm{MHz}, \mathrm{CDCl}_{3}\right): \delta$ 7.50 (1H, d, J 8.6 Hz, Ar-H), 7.05-6.91 (2H, m, Ar-H), $6.15(1 \mathrm{H}, \mathrm{d}, J 1.0 \mathrm{~Hz}, \mathrm{Ar}-\mathrm{H}), 5.82$ (1H, d, $J 2.25 \mathrm{~Hz}, \mathrm{H}-1), 5.20-5.13$ (2H, m, H-3, H-4), 5.02 (1H, m, H-2), 4.88 (1H, d, J $1.8 \mathrm{~Hz}, \mathrm{H}-5)$, $3.75\left(3 \mathrm{H}, \mathrm{s}, \mathrm{COOCH}_{3}\right), 2.37\left(3 \mathrm{H}, \mathrm{s}, \mathrm{CH}_{3}\right), 2.15\left(3 \mathrm{H}, \mathrm{s}, \mathrm{OCOCH}_{3}\right), 2.10\left(3 \mathrm{H}, \mathrm{s}, \mathrm{OCOCH}_{3}\right), 2.07$ $\left(3 \mathrm{H}, \mathrm{s}, \mathrm{OCOCH}_{3}\right) .{ }^{13} \mathrm{C} \mathrm{NMR}\left(125 \mathrm{MHz}, \mathrm{CDCl}_{3}\right): \delta 169.34(\mathrm{C}), 169.26(\mathrm{C}), 168.8(\mathrm{C}), 167.8(\mathrm{C})$, $160.8(\mathrm{C}), 158.4(\mathrm{C}), 154.8(\mathrm{C}), 152.1(\mathrm{C}), 125.8(\mathrm{CH}), 115.4(\mathrm{C}), 113.1(\mathrm{CH}), 112.7(\mathrm{CH})$, 104.4 (CH), 95.5 (CH), 67.6 (CH), $66.8(\mathrm{CH}), 66.5(\mathrm{CH}), 52.7(\mathrm{CH}), 20.7\left(\mathrm{CH}_{3} \times 2\right), 20.5\left(\mathrm{CH}_{3}\right)$, $18.6\left(\mathrm{CH}_{3} \times 2\right)$. HRMS $\left(\mathrm{FAB}, \mathrm{MH}^{+}\right)$: $\mathrm{m} / z$ Calcd for $\mathrm{C}_{23} \mathrm{H}_{25} \mathrm{O}_{12}: 493.1346$, Found: 493.1335 . 
Methyl 4-methyl-3-undecyl-coumarin-7-yl-2,3,4-tri- $O$-acetyl- $\alpha$-L-idopyranuronate $\quad(14 \alpha)$. Purification of the crude residue was carried out by flash column chromatography (EtOAc/hexanes 1/3) to furnish the product $\mathbf{1 4 \alpha}(74 \mathrm{mg}, 37 \%)$ and its $\beta$-isomer $(60 \mathrm{mg}, 30 \%)$. ${ }^{1} \mathrm{H}$ NMR (400 MHz, $\left.\mathrm{CDCl}_{3}\right): \delta 7.49(1 \mathrm{H}, \mathrm{dd}, J$ 8.2, $1.0 \mathrm{~Hz}, \mathrm{Ar}-\mathrm{H}), 7.02-6.93(2 \mathrm{H}, \mathrm{m}, \mathrm{Ar}-\mathrm{H})$, $5.81(1 \mathrm{H}, \mathrm{d}, J 2.6 \mathrm{~Hz}, \mathrm{H}-1), 5.22-5.15(2 \mathrm{H}, \mathrm{m}, \mathrm{H}-3, \mathrm{H}-4), 5.08-5.01(1 \mathrm{H}, \mathrm{m}, \mathrm{H}-2), 4.89$ (1H, d, $J$ $2.3 \mathrm{~Hz}, \mathrm{H}-2), 3.75\left(3 \mathrm{H}, \mathrm{s}, \mathrm{COOCH}_{3}\right), 2.60\left(2 \mathrm{H}, \mathrm{t}, J 7.7 \mathrm{~Hz}, \mathrm{CH}_{2}\right), 2.35\left(3 \mathrm{H}, \mathrm{s}, \mathrm{CH}_{3}\right), 2.14(3 \mathrm{H}, \mathrm{s}$, $\left.\mathrm{OCOCH}_{3}\right), 2.09\left(3 \mathrm{H}, \mathrm{s}, \mathrm{OCOCH}_{3}\right) 2.07\left(3 \mathrm{H}, \mathrm{s}, \mathrm{OCOCH}_{3}\right), 1.54-1.42\left(2 \mathrm{H}, \mathrm{m}, \mathrm{CH}_{2}\right), 1.41-1.11$ $\left(16 \mathrm{H}, \mathrm{m},\left(\mathrm{CH}_{2}\right)_{8}\right), 0.85\left(3 \mathrm{H}, \mathrm{t}, J 6.9 \mathrm{~Hz}, \mathrm{CH}_{3}\right) .{ }^{13} \mathrm{C} \mathrm{NMR}\left(125 \mathrm{MHz}, \mathrm{CDCl}_{3}\right): \delta 169.4(\mathrm{C}), 169.3$ (C), $168.9(\mathrm{C}), 167.8(\mathrm{C}), 161.7(\mathrm{C}), 157.3(\mathrm{C}), 153.3(\mathrm{C}), 145.4(\mathrm{C}), 125.6(\mathrm{CH}), 125.1(\mathrm{C})$, $116.2(\mathrm{C}), 112.4(\mathrm{CH}), 104.2(\mathrm{CH}), 95.6(\mathrm{CH}), 67.5(\mathrm{CH}), 66.9(\mathrm{CH}), 66.6(\mathrm{CH}), 66.5(\mathrm{CH}), 52.7$ $\left(\mathrm{CH}_{3}\right), 31.9\left(\mathrm{CH}_{2}\right), 29.7\left(\mathrm{CH}_{2}\right), 29.59\left(\mathrm{CH}_{2}\right), 29.56\left(\mathrm{CH}_{2}\right), 29.47\left(\mathrm{CH}_{2}\right), 29.3\left(\mathrm{CH}_{2}\right), 28.7\left(\mathrm{CH}_{2}\right)$, $27.6\left(\mathrm{CH}_{2}\right), 22.6\left(\mathrm{CH}_{2}\right), 20.7\left(\mathrm{CH}_{3} \times 2\right), 20.5\left(\mathrm{CH}_{3}\right), 14.8\left(\mathrm{CH}_{3}\right), 14.1\left(\mathrm{CH}_{3}\right)$. HRMS (FAB, $\left.\mathrm{MH}^{+}\right): m / z$ Calcd for $\mathrm{C}_{34} \mathrm{H}_{47} \mathrm{O}_{12}: 647.3068$, Found: 647.3088.

\section{General procedure for the ester hydrolysis}

In separate reaction flasks, compounds $15(10 \mathrm{mg}, 0.02 \mathrm{mmol})$ and $16(33 \mathrm{mg}, 0.05 \mathrm{mmol})$ were dissolved in $300 \mu \mathrm{L}$ and $510 \mu \mathrm{L}$ (10:1) THF-water mixture, respectively. To each solution, 90 $\mu \mathrm{L} \mathrm{LiOH}_{(\mathrm{aq})}$ was added at $-10{ }^{\circ} \mathrm{C}$. The reaction mixtures were allowed to attain $0{ }^{\circ} \mathrm{C}$ in a $2-\mathrm{h}$ period. The $\mathrm{pH}$ value of each solution was adjusted to approximately 7 by adding Dowex 50WX8-200 ion-exchange resin. The reaction solutions were filtered separately, and the resulting filtrates were concentrated in vacuo to obtain products 4 and 15 .

4-Methylcoumarin-7-yl- $\alpha$-L-iduronic acid (4). The ${ }^{1} \mathrm{H}$ NMR of this compound conforms to previous report. ${ }^{6}{ }^{1} \mathrm{H}$ NMR $\left(500 \mathrm{MHz}, \mathrm{CD}_{3} \mathrm{OD}\right): \delta 7.67(1 \mathrm{H}, \mathrm{d}, J 8.6 \mathrm{~Hz}, \mathrm{Ar}-\mathrm{H}), 7.51-7.42(2 \mathrm{H}$, m, Ar-H), $6.16(1 \mathrm{H}, \mathrm{s}, \mathrm{Ar}-\mathrm{H}), 5.61(1 \mathrm{H}, \mathrm{d}, J 6.5 \mathrm{~Hz}, \mathrm{H}-1), 4.39$ (1H, d, J 5.3 Hz, H-5), 3.78-3.71 (1H, m, H-4), 3.64 (1H, t, J 8.2 Hz, H-3), 3.52 (1H, t, J 7.1 Hz, H-2), $2.44\left(3 \mathrm{H}, \mathrm{s}, \mathrm{CH}_{3}\right)$.

4-Methyl-3-undecyl-coumarin-7-yl-a-L-iduronic acid (15). ${ }^{1} \mathrm{H} \mathrm{NMR}\left(500 \mathrm{MHz}, \mathrm{CD}_{3} \mathrm{OD}\right): \delta$ $7.62(1 \mathrm{H}, \mathrm{d}, J 8.7 \mathrm{~Hz}, \mathrm{Ar}-\mathrm{H}), 7.44-7.36(2 \mathrm{H}, \mathrm{m}, \mathrm{Ar}-\mathrm{H}), 5.61(1 \mathrm{H}, \mathrm{d}, J 6.1 \mathrm{~Hz}, \mathrm{H}-1), 4.41$ (1H, d, $J 4.9 \mathrm{~Hz}, \mathrm{H}-5), 3.81-3.73$ (1H, m, H-4), 3.67 (1H, t, J 7.9 Hz, H-3), 3.54 (1H, t, J $6.9 \mathrm{~Hz}, \mathrm{H}-2)$, $2.61\left(2 \mathrm{H}, \mathrm{t}, J 7.8 \mathrm{~Hz}, \mathrm{CH}_{2}\right), 2.41\left(3 \mathrm{H}, \mathrm{s}, \mathrm{CH}_{3}\right), 1.55-1.44\left(2 \mathrm{H}, \mathrm{m}, \mathrm{CH}_{2}\right), 1.44-1.18(16 \mathrm{H}, \mathrm{m}$, $\left.\left(\mathrm{CH}_{2}\right)_{8}\right), 0.89\left(3 \mathrm{H}, \mathrm{t}, J 6.9 \mathrm{~Hz}, \mathrm{CH}_{3}\right) .{ }^{13} \mathrm{C} \mathrm{NMR}\left(125 \mathrm{MHz}, \mathrm{CD}_{3} \mathrm{OD}\right): \delta 180.3(\mathrm{C}), 164.1(\mathrm{C})$, $161.1(\mathrm{C}), 154.5(\mathrm{C}), 148.7(\mathrm{C}), 126.9(\mathrm{CH}), 124.6(\mathrm{C}), 116.3(\mathrm{C}), 114.8(\mathrm{CH}), 104.8(\mathrm{CH}), 99.3$ $(\mathrm{CH}), 74.5(\mathrm{CH}), 73.8(\mathrm{CH}), 72.4(\mathrm{CH}) 33.0\left(\mathrm{CH}_{2}\right), 30.71\left(\mathrm{CH}_{2}\right), 30.68\left(\mathrm{CH}_{2}\right), 30.55\left(\mathrm{CH}_{2}\right), 30.4$ $\left(\mathrm{CH}_{2}\right), 29.8\left(\mathrm{CH}_{2}\right), 28.3\left(\mathrm{CH}_{2}\right), 24.3\left(\mathrm{CH}_{2}\right), 23.7\left(\mathrm{CH}_{2}\right), 15.0\left(\mathrm{CH}_{3}\right), 14.4\left(\mathrm{CH}_{3}\right)$. HRMS (FAB, $\left.\mathrm{MH}^{+}\right): m / z$ Calcd for $\mathrm{C}_{27} \mathrm{H}_{39} \mathrm{O}_{9}: 507.2594$, Found: 507.2301.

\section{Acknowledgements}

This work was supported by the National Science Council (NSC 97-2113-M-001-033-MY3, NSC 98-2119-M-001-008-MY2) and Academia Sinica. 


\section{References}

1. Brady, R. O. Annu. Rev. Med. 2006, 57, 283.

2. Muenzer, J. J. Pediatr. 2004, 144, S27.

3. Coutinho, M. F.; Lacerda, L.; Alves, S. Biochem. Res. Int. 2012, 2012, 471325.

4. Peters, C.; Shapiro, E. G.; Krivit, W. J. Pediatr. 1998, 133, 7.

5. Mandelli, J.; Wajner, A.; Pires, R. F.; Giugliani, R.; Coelho, J. C. Arch. Med. Res. 2002, 33, 20.

6. Baggett, N.; Samra, A. K.; Smithson, A. Carbohydr. Res. 1983, 124, 63.

7. Baggett, N.; Case, M. A.; Darby, P. R.; Gray, C. J. Carbohydr. Res. 1990, 197, 295.

8. (a) Srivastava, R. M.; Hudson, N.; Seymour, F. R.; Weissmann, B. Carbohydr. Res. 1978, 60, 315. (b) Hung, S.-C.; Thopate, S. R.; Puranik, R. Carbohydr. Res. 2001, 331, 369. (c) Hung, S.-C.; Chen, C.-S. J. Chin. Chem. Soc. 2000, 47, 1257. (d) Lee, J.-C.; Chang, S.-W.; Liao, C.-C.; Chi, F.-C.; Chen, C.-S.; Wen, Y.-S.; Wang, C.-C.; Kulkarni, S. S.; Puranik, R.; Liu, Y.-H.; Hung, S.-C. Chem.-Eur. J. 2004, 10, 399.

9. (a) Kulkarni, S. S.; Chi, F.-C.; Hung, S.-C. J. Chin. Chem. Soc. 2004, 51, 1193. (b) Lee, J.C.; Lu, X.-A.; Kulkarni, S. S.; Wen, Y.-S.; Hung, S.-C. J. Am. Chem. Soc. 2004, 126, 476. (c) Lu, L.-D.; Shie, C.-R.; Kulkarni, S. S.; Pan, G.-R.; Lu, X.-A.; Hung, S.-C. Org. Lett. 2006, 8, 5995. (d) Hung, S.-C.; Lu, X.-A.; Lee, J.-C.; Chang, M. D.-T.; Fang, S.-1.; Fan, T.C.; Zulueta, M. M. L.; Zhong, Y.-Q. Org. Biomol. Chem. 2012, 10, 760.

10. Subhas Bose, D.; Rudradas, A. P.; Hari Babu, M. Tetrahedron Lett. 2002, 43, 9195.

11. Yu, H. N.; Furukawa, J.-i.; Ikeda, T.; Wong, C.-H. Org. Lett. 2004, 6, 723. 